\title{
PENGEMBANGAN BAHAN AJAR BERBASIS WEB UNTUK MATAKULIAH DESAIN PESAN
}

\section{DEVELOPMENT OF TEACHING MATERIALS FOR WEB-BASED DESIGN COURSE BOOK}

\author{
Mesach Dayunison Parumbuan \\ Email:mesach.parumbuan@gmail.com
}

\begin{abstract}
Abstrak: Tujuan penelitian dan pengembangan ini adalah menghasilkan bahan ajar berbasis web yang layak dan valid untuk matakuliah desain pesan di Program Studi Teknologi Pendidikan, Universitas Negeri Makassar, dan efektif meningkatkan hasil belajar mahasiswa. Model penelitian dan pengembangan yang digunakan adalah model Lee \& Owens (2004). Hasil ujicoba terhadap ahli, pengampu matakuliah dan mahasiswa menunjukkan bahan ajar berbasis web layak dan valid digunakan sebagai bahan ajar berbasis web dalam matakuliah desain pesan di Program Studi Teknologi Pendidikan Universitas Negeri Makassar, dan efektif dalam meningkatkan hasil belajar mahasiswa.
\end{abstract}

Kata kunci: Bahan ajar berbasis web, web, desain pesan.

\begin{abstract}
The research and development aims to develop web-based instructional material (learning object) which is feasible and valid for message design courses in Educational Technology Under Graduate School, State University of Makassar, and effectively to improve student achievement. The research and development model use is Lee and Owens Models (2004). The result of the experiment to experts, lecturer of the message design courses, and students show that the web-based instructional materials is feasible and valid, so on effective in improve student achievement.
\end{abstract}

Keywords: web-based instructional materials, web, message design

Perubahan paradigma pendidikan ke arah pembelajaran yang berpusat pada pebelajar (learner-centered), telah mengubah peran pembelajar dalam proses pembelajaran. Pebelajar dipandang sebagai pusat dari proses pembelajaran sedangkan pembelajar sebagai fasilitator dituntut untuk dapat mendesain lingkungan yang efektif, efisen, menarik dan menyenangkan yang dapat memfasilitasi belajar pebelajar.

Salah satu alternatif yang dapat membantu pembelajar untuk menciptakan lingkungan belajar tersebut adalah dengan menggunakan teknologi. Teknologi dapat membantu guru menjadi seorang manajer kreatif yang sanggup menciptakan beragam pengalaman belajar (Smaldino, Lowther \& Russel, 2008: 13). Teknologi dapat menjadi "partner intelektual" bagi pebelajar dengan melibatkan, mendukung mereka dalam belajar, dan teknologi adalah lingkungan yang melibatkan pebelajar untuk menggunakan strategi belajar kognitif dan keterampilan berpikir kritis (Jonassen, Howland, Moore, dan
Marra dalam Smaldino, Lowther \& Russel, 2008: 37). Bahkan teknologi memainkan peran sentral dalam segala aspek dari paradigma pembelajaran yang berpusat pada pebelajar (learner-centered paradigm) (Reigeluth \& Carr-Chellman, 2009: 16).

Sejalan dengan hal tersebut, maka salah satu teknologi yang dapat digunakan oleh pembelajar untuk menciptakan lingkungan belajar adalah teknologi world wide web atau web. web memungkinkan penyajian materi atau bahan ajar dalam berbagai format seperti teks, data, audio, video, dan animasi (Smaldino, Lowther, \& Russel, 2008:193). Web memungkinkan proses komunikasi secara langsung dan tertunda (Clark \& Mayer, 2003: 22), interaksi dapat terjadi antara pebelajar dengan konten, pembelajar dengan pebelajar, dan pebelajar dengan sesama pebelajar (Moore; Northrup \& Rasmussen, dalam Wang \& Hsu, 2009:77). Selain itu, aktivitas penilaian seperti penilaian 
partisipasi pebelajar dan penugasan juga dapat dilakukan.

Teknologi web memiliki pontensi yang sangat besar dalam meningkatkan mutu dan kualitas pendidikan khususnya pembelajaran. Namun, kenyataan dilapangan khususnya di Program Studi Teknologi Pendidikan Universitas Negeri Makassar, pemanfaatan web dalam pembelajaran masih sangat minim, walaupun situs web telah ada, baru satu matakuliah yang menerapkan pembelajaran berbasis web atau $e$ learning.

Pada umumnya dosen masih menyajikan materi perkuliahan secara verbal dikelas, dan penggunaan media presentasi seperti komputer/laptor dan LCD proyektor yang belum optimal.

Secara khusus, hasil pengamatan pengembang pada matakuliah desain pesan, proses pembelajaran yang berlangsung masih terpusat pada dosen, bahan ajar yang dibuat oleh dosen masih sangat abstrak, hanya didominasi oleh teks dan kurang memperhatikan kaidah-kaidah dalam penyusunan bahan ajar menyebabkan mahasiswa kesulitan memahami materi kuliah.

Matakuliah desain pesan adalah salah satu matakuliah yang sangat penting dipahami dan dikuasai dengan baik oleh mahasiswa Program Studi Teknologi Pendidikan Universitas Negeri Makassar, karena tugas-tugas mahasiswa mulai dari semester awal hingga akhir sebgaian besar berkenaan dengan mendesain suatu produk, baik itu media presentasi, buku, web, video, audio dan sebagainya, dimana prinsip-prinsip dalam mendesain pesan sangat dibutuhkan. Juga, bukan hanya untuk mendukung mahasiswa dalam studi tetapi ketika sudah terjun ke dunia kerja, keterampilan dalam mendesain pesan sangat dibutuhkan.

Berdasarkan pemaparan di atas, maka solusi yang pengembang tawarkan ialah mengembangkan bahan ajar berbasis web untuk mata kuliah desain pesan. Bahan ajar ini akan menyajikan materi matakuliah desain pesan dalam beragam format seperti teks, data, audio, video dan animasi untuk memfasilitasi beragam gaya belajar mahasiswa. Urutan penyajian pokok bahan dimulai dengan menyajikan konsep dasar desain pesan, hubungan desain pesan dengan teknologi pendidikan, prinsip-prinsip desain pesan, dan langkahlangkah sistematis dalam mendesain pesan.

Bahan ajar ini ditempatkan pada program Sistem Manajemen Pembelajaran (LMS), suatu program berbasis web yang dibuat untuk menciptakan lingkungan belajar jarak jauh. Bahan ajar ini dapat diakses melalui internet (online) melalui situs www.iamdesigner.web.id.

\section{METODE}

Penelitian dan pengembangan bahan ajar berbasis web untuk matakuliah desain pesan ini menggunakan model penelitian dan pengembangan Lee \& Owens (2004). Langkah-langkah dalam model ini ialah 1) need assessment \& front-end analysis (front-end analysis terdiri atas audience analysis, technology analysis, situational analysis, task analysis, critical incident analysis, issue analysis, objective analysis, media analysis, extant data analysis, dan cost analysis); 2) design; 3) development; 4) implementation; 5) evaluation. Penelitian dan pengembangan ini melibatkan ahli ahli isi, ahli media dan ahli desain, dosen pengampu matakuliah desain pesan dan mahasiswa Program Studi Teknologi Pendidikan, Universitas Negeri Makassar, angkatan 2013.

Jenis data yang diperoleh adalah data kuantitatif berupa skor rata-rata hasil penilaian angket dan skor hasil belajar belajar mahasiswa setelah mengikuti pembelajaran. Sedangkan data kualitatif merupakan hasil angket berupa saran dan komentar dari subjek coba. Data kuantitatif dianlisis dengan menggunakan metode analisis statisitik deskriptif, sedangkan data kuantitatif dianalisis menggunakan metode analisis deskriptif kualitatif.

Desain uji coba produk pengembangan dimulai dengan uji coba terhadap ahli isi, ahli media dan ahli desain, setelah produk direvisi dilakukan uji perorangan terhadap dosen pengampu matakuliah dan 3 orang mahasiswa, setelah produk direvisi dilakukan uji kelompok kecil 9 orang mahasiswa dan setelah produk direvisi, terakhir, dilakukan uji 
lapangan terhadap 34 orang mahasiswa. Kemudian setelah produk di uji coba, produk bahan ajar diimplementasikan ke dalam pembelajaran untuk menilai tingkat efektivitas produk bahan ajar. Pembelajaran dilaksanakan secara online dan berlangsung selama 1 (satu) bulan, diikuti oleh 34 orang mahasiwa.

\section{HASIL}

Berdasarkan hasil penilain ahli isi, produk bahan ajar, panduan dosen dan panduan mahasiswa dinyatakan sangat sesuai dan layak digunakan dalam matakuliah desain pesan dengan persentase skor penilaian sebesar $98 \%$ yang berarti produk masuk dalam kategori sangat layak (81\%-100\%). Berdasarkan hasil penilaian ahli media, diperoleh persentase skor ratarata sebesar $92 \%$ yang berarti produk masuk dalam kategori sangat layak $(81 \%$ 100\%). Terdapat saran dan komentar berkaitan dengan penambahan sumbersumber belajar, tampilan web pada smarthphone, namun secara umum bahan ajar dinyatakan layak dan valid. Sedangkan untuk panduan dosen dan panduan mahasiswa terdapat saran dan komentar berkaitan dengan pembuatan panduan dalam bentuk cetak, gambar yang perlu diperbesar (zoom), namun secara umu panduan layak dan valid digunakan. Berdasarkan hasil penilaian ahli desain diperoleh persentase skor rata-rata sebesar 96\% yang berarti masuk dalam kategori sangat layak (81\%-100\%). Terdapat saran dan komentar berkaitan dengan penambahan aktivitas penilaian dan sumber belajar, namun secara umum bahan ajar dan panduan dinyatakan sudah baik atau layak.

Setelah produk direvisi, dilakukan uji coba perorangan terhadap dosen pengampu matakuliah desain pesan dan 3 orang mahasiwa Berdasarkan hasil penilaian dosen pengampu matakuliah diperoleh persentase skor rata-rata sebesar 95\% yang berarti produk masuk dalam kategori sangat layak (81\%-100\%). Sedangkan hasil penilaian 3 orang mahasiswa diperoleh persentase skor ratarata sebesar $81 \%$ yang berarti produk masuk dalam kategori sangat layak $(81 \%$ $100 \%)$. Terdapat saran dan komentar dari uji perorangan terhadap 3 orang mahasiswa yang berkaitan dengan kesalahan pengetikan, desain materi dalam bentuk presentasi (pptx) dibuat lebih menarik lagi. Setelah produk direvisi, dilakukan uji coba kelompok kecil terhadap 9 orang mahasiwa, berdasarkan hasil penilaian uji coba kelompok kecil diperoleh persentase skor rata-rata sebesar $78 \%$ yang berarti produk masuk kategori layak $(61 \%-80 \%)$. Terdapat saran dan komentar yang berkaitan dengan menyediakan menu login pada web, kemenarikan aplikasi flipbook sebagai salah satu bentuk/format materi dan panduan. Berdasarkan hasil uji lapangan terhadap 34 orang mahasiwa diperoleh persentase skor rata-rata sebesar $83 \%$ yang berarti produk masuk kategori sangat layak (81\%-100\%).

Setelah bahan ajar di uji coba, bahan ajar diimplementasikan ke dalam pembelajaran untuk menilai tingkat efektivitas bahan ajar. Secara umum, pembelajaran berlangsung dengan baik. Persentase jumlah mahasiswa yang lulus atau mencapai standar kelulusan sebesar $85 \%$ menunjukkan bahan ajar efektif dalam meningkatkan hasil belajar mahasiswa.

\section{PEMBAHASAN}

Setelah melalaui tahap penelitian dan pengembangan dengan menggunakan model pengembangan Lee \& Owens (2004), maka diperoleh bahan ajar berbasis web untuk matakuliah desain pesan di Program Studi Teknologi Pendidikan Universitas Negeri Makassar yang layak dan efektif meningkatkan hasil belajar mahasiswa. Bahan ajar berbasi web ini diberi nama E-Resource Message Design, dan dapat diakses secara online melalui situs www.iamdesigner.web.id.

Pengembangan bahan ajar berbasis web untuk matakuliah desain pesan di Program Studi Teknologi Pendidikan Universitas Negeri Makassar didasarkan atas kenyataan dilapangan. Selain kondisi nyata dilapangan, pemilihan web sebagai solusi tidak terlepas dari teori-teori pendukung dan hasil penelitian terdahulu. Antara lain teori yang dikemukakan oleh Smaldino, Lowther \& Russel, 2008, Clark dan Mayer 2003, Moore, 1989; Northrup 
\& Rasmussen, 2009, Smith, 2004, dsb., dan hasil-hasil penelitian pengembangan web sebagai bahan ajar oleh Ekawaty, 2012 dan Widodo, 2008.

Penilaian dari para ahli yang sangat signifikan berasal dari ahli media dan ahli desain yang berkaitan dengan pembuatan panduan dalam format cetak, penambahan sumber-sumber belajar, dan aktivitas penilaian. revisi telah dilakukan dengan menambahkan artikel, jurnal, link ke situs yang berkaitan dengan materi dan penambahan aktivitas penyimpulan. Revisi ini juga didukung oleh teori bahwa pembelajaran berbasis web yang didesain dengan baik, berdasarkan model desain pembelajaran, harus menyediakan semua informasi, contoh, dan aktivitas yang dibutuhkan pebelajar (Herridge Group Inc., 2004:17). Sedangkan saran dan komentar dari mahasiwa lebih bersifat teknis yakni berkaitan dengan tampilan, ukuran dan letak gambar, kesalahan pengetikan juga telah direvisi.

Kajian bahan ajar setelah dilakukan revisi meliputi aspek-aspek utama dari bahan ajar, yaitu: tampilan web, panduan bahan ajar dan bahan ajar. Tampilan web adalah aspek yang sangat penting dari suatu bahan ajar berbasis web, berdasarkan uji coba terhadap mahasiswa, secara umum mengatakan bahwa tampilan web kurang menarik dan monoton. Hal ini wajar karena LMS sebagai wadah memiliki kelemahan pada tampilan yang menjemukkan dan kaku, tidak seperti web jejaring sosial pada umumnya (Pina, 2010: 5). Walaupun demikian beberapa mahasiswa menyatakan secara umum bahan ajar berbasis web sangat menarik dan menambah minat belajar mereka untuk mendesain pesan. Tampilan halaman awal dari bahan ajar ini terdiri atas judul/nama bahan ajar. gambar-gambar slide, menu login, menu utama: tentang bahan ajar, panduan bahan ajar, bahan ajar; blok news, dan blok komen. Desain halaman awal ini bertujuan untuk member kemudahan pada mahasiswa untuk melakukan navigasi dalam memilih materi yang dibutuhkan dan memudahkan pengelola untuk mengatur isi pembelajaran dan administrasi (Pina, 2010:4). Tampilan halaman awal web ditunjukkan pada Gambar 1.
Tentang bahan ajar merupakan menu yang disediakan untuk memberikan informasi kepada pengguna, antara lain mengenai pengembang bahan ajar, deskripsi singkat bahan ajar, tujuan bahan ajar dan desain bahan ajar Menu tentang bahan ajar terdiri atas file tentang bahan ajar serta fasilitas komunikasi forum dan chat. Berdasarkan hasil uji coba terhadap mahasiswa tidak ditemukan saran dan komentar yang berkaitan dengan tentang bahan ajar atau petunjuk umum. Jadi tidak dilakukan revisi terhadap tentang bahan ajar. tampilan tentang bahan ajar ditunjukkan pada Gambar 2.

Panduan bahan ajar terdiri atas panduan dosen dan panduan mahasiswa. Panduan dosen dan panduan mahasiswa disusun berdasarkan teori bahwa "panduan merupakan komponen dari bahan ajar yang sangat penting karena memuat master strategi bagi pebelajar dan menjelaskan apa langkah pertama, kedua, ketiga dan selanjutnya yang mereka dapat lakukan" (Dick dan Carey, 1978: 127). Panduan dosen terdiri atas file panduan dalam bentuk/format pdf dan flipbook, dan fasilitas komunikasi FAQ dan chat yang dapat digunakan untuk bertanya mengenai panduan. Berdasarkan hasil penilaian terhadap panduan dosen oleh ahli ditemukan saran dan komentar yang sifatnya teknis terkait perlunya diperbesar (zoom) gambar yang digunakan. Panduan mahasiswa terdiri atas file panduan dalam bentuk/format pdf dan flipbook, dan fasilitas komunikasi FAQ dan chat yang dapat digunakan untuk bertanya mengenai panduan. . Berdasarkan hasil uji coba terhadap mahasiswa, terdapat revisi yang berkaitan dengan kesalahan pengetikan, ukuran gambar dan penambahan panduan dalam bentuk flipbook.

Bahan ajar ERMD terdiri atas 4 (empat) bagian, yakni materi, latihan, kolaborasi dan komunikasi, dan portofolio. Materi, terdiri atas materi utama, artikel dan sumber pengayaan. Latihan, terdiri atas mengerjakan latihan dan penyimpulan. Kolaborasi dan komunikasi, terdiri atas fasilitas forum (asynchrounus) dan chat (synchronous). Portofolio, terdiri atas fasilitas untuk mengumpulkan tugastugas. Pokok-pokok bahasan yang 
disajikan dalam bahan ajar berbasis web ini adalah A. Desain Pesan, B. Desain Pesan Dalam TEP, C. Prinsip-Prinsip Motivasi, D. Prinsip-Prinsip Persepsi, E. Prinsip-Prinsip Desain, dan F. LangkahLangkah Sistematis dalam Mendesain Pesan. Pokok-pokok bahasan disajikan secara berurutan dari atas ke bawah dalam satu halaman sehingga memudahkan pebelajar melihat dan memilih pokok bahasan yang akan mereka pelajari. Berdasarkan uji coba terhadap mahasiswa tidak ditemui saran dan komentar mengenai urutan penyajian pokok bahasan. Materi-materi yang disediakan terdiri atas materi utama, materi penunjang, dan materi pengayaan. Materi utama dalam satu pokok bahasan didesain dalam format dokumen PDF, PowerPoint, dan FlipBook. Sedangkan materi penunjang berupa artikel, jurnal, video, audio, dan animasi. Materi pengayaan berupa link ke web sumber yang dilekatkan (embedded). Beragamnya format materi dan desain isi/konten ini didasarkan atas kebutuhan untuk mengakomodir gaya belajar mahasiswa yang beragam, hal ini juga merupakan landasan dan syarat dari desain konten/informasi dari sebuah learning object. Cooper \& Varma, 1997 menyatakan bahwa pembelajaran yang efektif mengakomidir progress individu pada level yang berbeda, mencakup materi-materi yang berbeda, dan bahkan berpartisipasi dalam aktivitas yang berbeda. (dalam Smaldino, Lowther \& Russell, 2008: 18). Pemilihan ukuran huruf didasarkan atas teori bahwa teks yang dibaca dengan cara berkelanjutan harus memiliki ukuran antara sembilan sampai sebelas pika poin (Tinker, 1963; Haber and Haber, 1981; Benson, 1985; Braden, 1983, 1985, dalam Petterson, 2003:3), dan untuk mempertahankan perhatian belajar dan meningkatkan percaya diri, tiap baris hanya terdiri atas delapan hingga sepuluh kata (Keller dan Burkman, dalam Fleming dan Levie, 1993:3).

$$
\text { Latihan meningkatkan }
$$

kemungkinan mahasiswa mengalami belajar. Latihan meningkatkan retensi dan kemampuan untuk mengaplikasikan pengetahuan, keterampilan dan sikap baru (Smaldino, Lowther dan Russell (2008:18),. Bahkan latihan menghadirkan belajar yang lebih bermakna (deeper) dan lebih tahan lama (longer lasting) (Morrison \& Lowther, 2005 dalam Smaldino, Lowther dan Russell, 2008:18). Latihan dalam bahan ajar ini terdiri atas latihan mengerjakan soal-soal dan penyimpulan. Soal-soal latihan dibuat berdasarkan tujuan khusus pembelajaran. Sedangkan penyimpulan membutuhkan keterlibatan mahasiswa untuk menuliskan kesimpulan mengenai materi yang telah mereka pelajari secara online dan dikerjakan secara bersamaan sesuai dengan waktu yang diberikan.

Fasilitas kolaborasi dan komunikasi memungkinkan mahasiswa untuk berinteraksi, berdiskusi dan bekerjasama dalam mengerjakan suatu proyek. Mahasiswa dapat memposting dokumen, kemudian menerima masukan atau komentar dari mahasiswa lainnya, dimikian juga dosen/pengajar dapat memanfaatkan fasilitas ini untuk menilai keaktifan mahasiswa dalam proses pembelajaran. Hal ini sesuai dengan teori bahwa dalam e-learning proses sosial melibatkan interaksi seperti bertanya dan menjawab pertanyaan, mem-posting dan mengomentari pesan, dan berkolaborasi pada suatu proyek Horton (2012:402). Dalam bahan ajar ini fasilitas kolaborasi dan komunikasi terdiri atas fasilitas chat dan forum.

Portofolio merupakan fasilitas untuk menilai hasil belajar mahasiswa. Penggunaan portofolio sebagai salah satu aspek penilaian karena karakteristik matakuliah desain pesan yang mengutamakan proses dan produk berupa rancangan desain pesan. Dasar dilakukannya penilaian portofolio ialah kesesuaian dengan karakteristik matakuliah desain pesan dan penilaian portofolio dapat menggambarkan prestasi mahasiswa menyangkut kemampuan mereka dalam merancang produk-produk desain pesan. Penilain portofolio juga sesuai dengan teori bahwa portofolio dapat melukiskan hasil kerja pebelajar baik proses dan produk, maupun menunjukkan pertumbuhan pebelajar (Smaldino, Lowther dan Russell, 2008: 13). Gambar 3. Menunjukkan tampilan salahsatu isi pokok bahasan. 


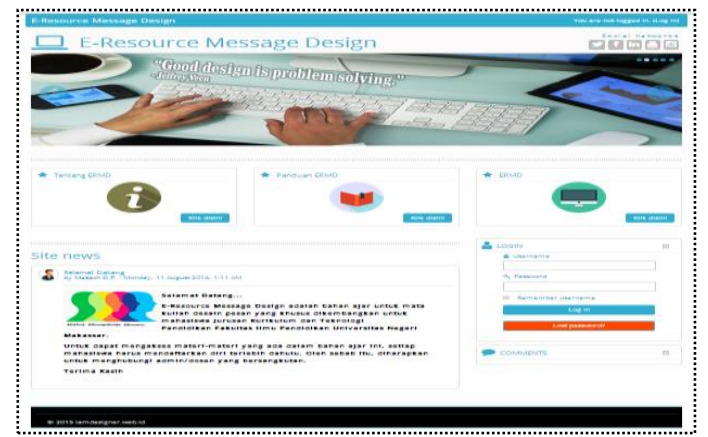

Gambar 1. Tampilan Halaman Awal Bahan Ajar Berbasis Web Untuk Matakuliah Desain Pesan (www.iamdesigner.web.id)

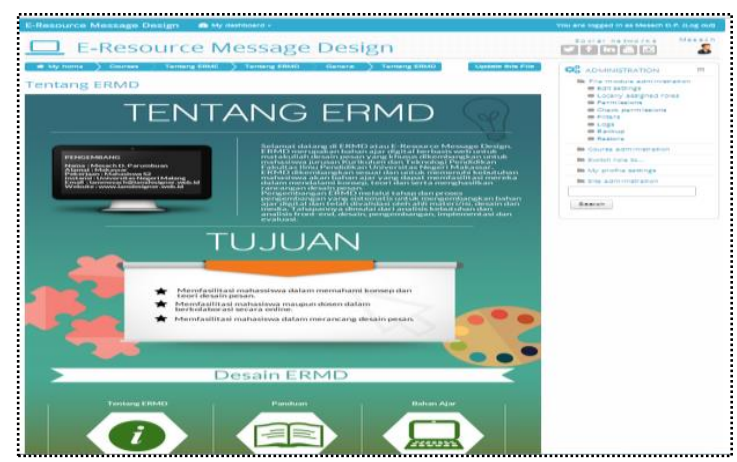

Gambar 2. Tampilan Tentang Bahan Ajar (ERMD)

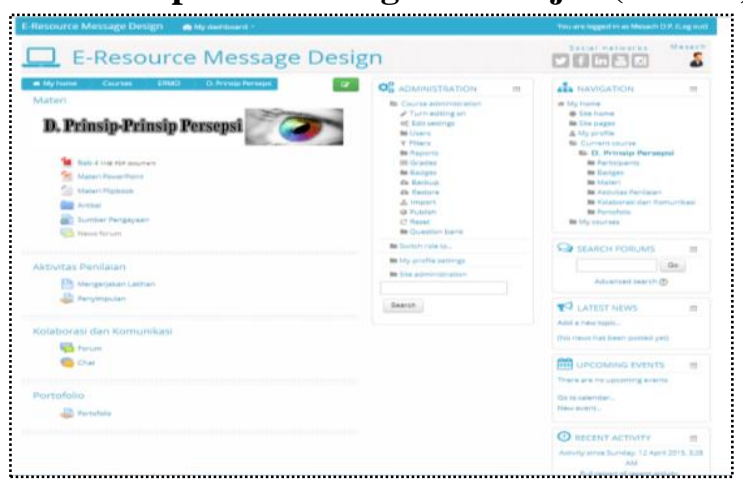

Gambar 2. Tampilan Isi Salah Satu Pokok Bahasan

\section{SIMPULAN DAN SARAN \\ Simpulan}

Berdasarkan hasil analisis data dan pembahasan. Penelitian dan pengembangan bahan ajar berberbasis web untuk matakuliah desain pesan di Program Studi Teknologi Pendidikan Universitas Negeri Makassar, layak dan efektif meningkatkan hasil belajar mahasiswa.

\section{Saran}

Saran pemanfaatan bahan ajar berbasis web adalah berkaitan dengan strategi pembelajaran yang sesuai dengan pembelajaran berbasis web atau e-learning harus dipahami dengan baik oleh dosen agar pembelajaran berjalan dengan efektif dan efisien. Saran diseminasi untuk bahan ajar berbasis web ini adalah mengkaji karakteristik mahasiswa dan ketersediaan fasilitas sebelum menggunakan bahan ajar. Saran untuk pengembangan produk lebih lanjut adalah sebaiknya software LMS di update secara berkelanjutan, desain web dibuat lebih menarik lagi, menambahkan materi desain pesan atau mengurangi sesuai kebutuhan.

\section{DAFTAR RUJUKAN}

Clark, R. C. \& Mayer, R. E. 2003. E-Learning and The Science of Instruction. Proven Guidelines for Consumers and Designer of Multimedia Learning. San Fransisco: John Wiley \& Sons, Inc.

Dick,W. \& Carey, L. 1978. The Systematic Design of Instruction. Illinois: Scott, Foresman and Company. 
Ekawaty. 2012. Pengembangan Bahan Ajar Kimia Berbasis Web Pada Materi Elektrokimia Berorientasi Chemoentrepreneurship Untuk Siswa Sekolah Menengah Kejuruan (SMK). Tesis tidak diterbitkan. Malang: PPs UM.

Fleming, M. dan Levie, W. H. 1993. Instructional Message Design: Principles from the Behavioral and Cognitif Sciences (Second Edition). Educational Technology Publications: Engglewood Cliffs, New Jersey.

Herridge Group Inc. 2004. The Use of Traditional Instructional Systems Design Models for eLearning. Herridge Group Inc.

Horton, W. 2012. E-Learning by Design $\left(2^{\text {nd }}\right.$ Edition). San Francisco, CA: Pfeiffer.

Lee, W. W. \& Owens, D. L. 2004. MultimediaBased Instructional Design (Second Edition). San Francisco CA: John Wiley \& Sons, Inc.

Petterson, R. 2003. Gearing Communications to the Cognitive Needs of Students: findings from visual literacy research. IIID, Preparing for the Future of Knowledge Presentation, Chicago, USA.

Pina, A. A. 2010. An Overview of Learning Management Systems. Dalam Kats, Yevim (Ed), Learning Management
System Technologies and Software Solution for Online Teaching: Tools and Aplications (hlm.1-9). New York: IGI Global. (CD-ROM: Learning Management System Technologies and Software Solution for Online Teaching: Tools and Aplications, 2010).

Reigeluth, C. M., \& Carr-Chellman. A. A. 2009. Understanding Instructional Theory. Dalam Instructional-Design Theories and Models, Building a Common Knowledge Base. Volume III. (Reigeluth, Charles M., \& CarrChellman. Alison A, Ed). New York. Routledge.

Smaldino, S. L., Lowther, D. L., \& Russel J. D. 2008. Instructional Technology and Media for Learning $9^{\text {th }}$ Edition. New Jersey. Pearson Education, Inc.

Wang, S-K. \& Hsu, H-Y. 2009. Using the ADDIE Model to Design Second Life Activities for Online Learners. TechTrends, Volume 53 Number 6. November-December, 2009: 76-81. (CD-ROM: TechTrends, 2009).

Widodo, R. B. 2008. Pengembangan Bahan Ajar Digital Dasar Rekayasa Perangkat Lunak Untuk Mahasiswa Teknologi Informasi Menggunakan Teori Elaborasi. Tesis tidak diterbitkan. Malang: PPs UM. 